\title{
Marine-based Natural Product
}

National Cancer Institute

\section{Source}

National Cancer Institute. Marine-based Natural Product. NCI Thesaurus. Code C106129.

Any substance or product derived from any organism that lives in bodies of fresh or salt water. 